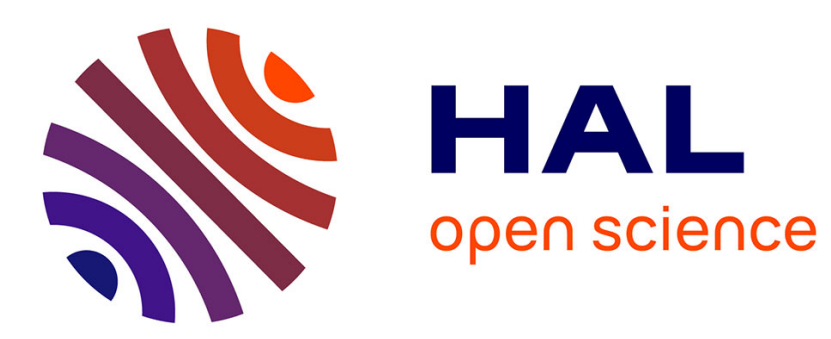

\title{
Trade, immiserising growth and the long-term neolithisation process of the Pitted Ware Culture \\ Serge Svizzero
}

\section{To cite this version:}

Serge Svizzero. Trade, immiserising growth and the long-term neolithisation process of the Pitted Ware Culture. Journal of Anthropological Archaeology, 2015, 40, pp.332-339. 10.1016/j.jaa.2015.10.002 . hal-02148984

\section{HAL Id: hal-02148984 \\ https://hal.univ-reunion.fr/hal-02148984}

Submitted on 6 Jun 2019

HAL is a multi-disciplinary open access archive for the deposit and dissemination of scientific research documents, whether they are published or not. The documents may come from teaching and research institutions in France or abroad, or from public or private research centers.
L'archive ouverte pluridisciplinaire HAL, est destinée au dépôt et à la diffusion de documents scientifiques de niveau recherche, publiés ou non, émanant des établissements d'enseignement et de recherche français ou étrangers, des laboratoires publics ou privés. 


\title{
Trade, immiserising growth and the long-term neolithisation process of the Pitted Ware Culture
}

\author{
Serge Svizzero \\ Faculté de Droit et d'Economie, Université de La Réunion, 15 Avenue René Cassin, BP 7151, 97715 Saint Denis, France
}

While agro-pastoralism has been introduced in northern Europe - southern Scandinavia from 4000 BC, a hunting and gathering culture - the Pitted Ware (3300-2300 BC) reappeared in this Neolithic context and left a central question: why it did not adopt agriculture despite contacts during one millennium with its neighbouring farming communities? We provide an explanation based on an economic mechanism related to trade between foragers and farmers. We demonstrate that the terms of trade of raw materials (mainly seal oil) extracted and sold by foragers have a tendency to decline in the long term in relation to the resources produced and sold by farmers. Neolithisation of northern Europe can therefore be viewed as the outcome of a long-term process based on trade in which hunter-gatherers get voluntarily involved without forecasting that it will, in the end, constraint most of them to give up their way of life.

\section{Introduction}

Although it is widely accepted that agro pastoralism first appeared in the Near East, its diffusion to Europe the so called neolithisation process is still, even eight decades after Childe's (1936) seminal publication, the purpose of major debates and con troversies among scholars. These debates are about the various theories explaining agriculture commencement (Svizzero and Tisdell, 2014) or the diffusion of agriculture (e.g. according to migrationists, indigenists or integrationists) (Zvelebil, 2001). Among these debates, a European region namely Northern Europe and Southern Scandinavia occupies a central place espe cially owing to the role played by successive hunter gatherers (HG hereinafter) cultures, the Ertebølle culture (5400 $\left.3950 \mathrm{BC}^{1}\right)$ and the Pitted Ware Culture (3300 2300 BC). Indeed, this region (denoted simply by 'Northern Europe' in the sequel) was in Europe one of the latest, just before Britain and Ireland, where agriculture arrived around 4000 BC (Rowley Conwy, 2011). Per se, this chronol ogy is not astonishing since agriculture spread from the Levant into Europe following a southeast northwest global movement. What is more surprising, is that agriculture spread rapidly into central Europe (with the LBK culture, $57004900 \mathrm{BC}$ ), and then stopped at

\footnotetext{
E-mail address: serge.svizzero@univ-reunion,fr
}

${ }^{1}$ Dates listed as "BC" are in calibrated years. the northern fringes of Europe (Dolukhanov et al., 2005). In this area were living the people of the Ertebølle culture (5400 3950 BC), a Mesolithic society of complex hunter gatherers for whom subsistence was mainly based on marine resources. Despite 1500 years of contacts from 5400 to $3950 \mathrm{BC}$ with the successive farming communities (LBK, its related "daughter cultures" and then $\mathrm{TRB}^{2} 43002800 \mathrm{BC}$ ) located on the southern border of their terri tory, the Ertebølle people did not adopt agriculture. It is only around $4000 \mathrm{BC}$ that agriculture spread into Northern Europe, within few centuries, with the TRB culture (Sørensen and Karg, 2012). This very long delay before the adoption of agriculture is intriguing for schol ars even if most of them are now aware of the potential challenges and potentially detrimental effects of farming (Bowles, 2011; Berbesque et al., 2014). Thus, the delayed introduction of agriculture in northern Europe has given rise to various explanations such as the role of migration, food crisis, the role of potentially abundant wild resources, and social competition among HG, the latter being largely supported in the literature (see e.g. Fischer, 2002). Recently an alter native explanation based on the impoverishment of foragers (Ertebølle) consequently to their trade with farmers (LBK to TRB) has been proposed (Svizzero, 2015).

\footnotetext{
2 TRB for the abbreviation of its German name, Tricherrandbecher or Trichterbecher; it is also called the Funnel Beaker Culture.
} 
Another astonishing episode occurred in northern Europe dur ing the Neolithic period. Indeed, in this region, the Neolithic spans from 4000 to $1800 \mathrm{BC}^{3}$ and encompasses three different cultures: two of them were agricultural the TRB (4000 $2800 \mathrm{BC})$ and subsequently the $\mathrm{BAC}^{4}(28002100 \mathrm{BC})$, and the third one was a hunting gathering culture mainly based on marine resources, the Pitted Ware Culture ${ }^{5}$ or PWC (3300 2300 BC). Thus, this region was characterised by a single farming culture during the Early Neolithic (4000 3300 BC) and the Late Neolithic (2200 1800 BC). In the interval, i.e. during the Middle Neolithic (3300 2200 BC), there was a cultural dualism with, on the one hand TRB and PWC during the Middle Neolithic A (3300 2800 BC) and, on the other hand, BAC and PWC during the Middle Neolithic B (2800 2300 $\mathrm{BC})$. In other words, while agriculture was present in northern Europe from $4000 \mathrm{BC}$, a hunting and gathering culture the PWC appeared about 800 years after the introduction of agriculture and it coexisted with farmers on the same territories during approx imately one millennium (Zvelebil, 2004). This sharply contrasts with other neolithisation trajectories which existed in northern Europe, such as in the northeast Atlantic archipelagos where recent studies have confirmed the rejection of marine resources (and thus of the hunting gathering lifestyle) by early farmers coinciding with the adoption of intensive dairy farming (Cramp et al., 2014).

Therefore, the existence of the PWC has led to intense debates among scholars (Larsson, 2003, 2004; Zvelebil, 2004), has did the persistence of hunting and gathering in other contexts (Svizzero and Tisdell, 2015). Recent archaeogenetic studies have provided useful answers about the origin and the destiny of the PWC (Eriksson, 2004; Fornander et al., 2008; Malmström et al., 2009, 2010, 2015; Skoglund et al., 2012, 2014). However one question remains open : it is about the attitude of the Pitted Ware people with respect to agriculture. Why they did not adopt agriculture despite numerous contacts during one millennium with their neighbouring farming communities? It is the aim of this paper to answer to this question. For that purpose, we provide an economic analysis of the consequences of the trade relationships between hunter gatherers (PWC) and farmers (TRB to BAC). While in archaeology and economic anthropology the limited attention given to trade and market exchange owes much to the broad influ ence of the substantivist approach (Polanyi, 1944), recent approaches have emphasised the theoretical and methodological issues surrounding the detection, development, and significance of markets in the preindustrial past (see e.g. Smith, 2004; Feinman and Garraty, 2010). Given these recent developments about the role of the market, we analyse how contact and exchange between foraging and farming communities were bound to play a key role as a vehicle for the adoption of farming, as it is assumed in the integrationist approach (Zvelebil and Rowley Conwy, 1984; Zvelebil, 2001). Characteristically, raw materials and produces of hunting and gathering such as furs, honey, and especially seal fat were exchanged by hunter gatherers for finished products such as axes and ornaments. Such structure of trade is similar to the one between developing and developed countries. The former are exporting commodities and raw materials while the latter are exporting manufactured goods. In the 1950s, and dealing with international trade between both groups of countries, some econ omists (Singer, 1950; Prebisch, 1950) have examined data over a long period of time suggesting that the terms of trade for primary commodity exporters did have a tendency to decline. They concluded that it is the very structure of the market which is

\footnotetext{
$31700 \mathrm{BC}$ is the beginning of the Bronze Age in this region.

4 BAC for 'Battle-Axe Culture' or 'Boat Axe Culture', which is a regional version of the Corded Ware culture complex.

${ }^{5}$ In the literature, the Pitted Ware Culture is also denoted by GRK for 'Gropkeramik'.
}

responsible for the existence of inequality in the world system. We assume that the structure of trade between foragers and farmers during the fourth to the third millennium in northern Europe was very similar to the one existing between developing and developed countries since the industrial revolution. ${ }^{6}$ Terms of trade were therefore unfavourable to Pitted Ware people because in order to feed a growing population, farmers have had to cultivate new lands characterise by lower fertility. The labour productivity in agri culture was therefore continuously decreasing, faster than the labour productivity of foragers. The price of agricultural products was grow ing faster than the price of raw materials and this meant a further deterioration of terms of trade. The unchanged structure of supply intensifies the structural dependency and, regardless of growth, there is no development but only "immiserising growth". The con cept of immiserising growth describes a situation where a mainly exporter country that grows, finds itself worse off because the terms of trade (relative prices) change too much against it. It was first pro posed by Bhagwati (1958); for a recent and complete statement of the various approaches of immiserising growth, see Pryor (2007). Facing immiserising growth, the Pitted Ware people have been con strained in the long term to adopt farming.

\section{The Pitted Ware Culture}

By 4000 BC, cultivation of cereals and domestication of cattle, pigs, sheep and goats were introduced as part of the TRB culture into northern Europe and across south Sweden, at least as far north as the river Dalälven. With the new economy followed a fairly homoge nous regional pottery tradition, similar in both style and technology from Skåne in the south to Uppland in the north. However, by 3300 BC in eastern Sweden a trajectory different from TRB was followed. There appeared here over time new local types of material culture, and a new subsistence system, with strong influences from neigh bouring HG in the north and east: this was the PWC.

\subsection{Geography and settlement location}

While the PWC is initially an eastern central Sweden phe nomenon, it quickly spreads along the east coast southwards, and to the large islands of the Baltic Sea, Gotland and Öland. ${ }^{7}$ As exemplified by one of the most important sites in Middle Sweden, the Alvastra pile dwelling in Östergötland, some sites were by all means constructed by the Middle Neolithic TRB and "taken over" by the PWC. Later, the PWC is also found in regions not previously part of the TRB community, i.e. in the north and on the islands of Åland in the east. Although it is still controversial among scholars, the PWC could also be present on the west coast of Sweden, in southern Norway (Hallgren, 2012), and in northern Denmark (Iversen, 2013) (see Fig. 1).

The location of the PWC sites is associated with the coasts, and the shores of big lakes, while the TRB sites are primarily situated on good arable soils. The abundant quantities of pottery at the PWC settlements make them fairly easy to discover. The vessels found display a wide variety of motifs in many different combina tions, but present on almost all the reconstructed vessels was at least one horizontal row of large, deep pits.

\subsection{Subsistence and diet}

There are indications that cultivation was practiced locally in eastern central Sweden (including on Gotland and Öland) during

\footnotetext{
${ }^{6}$ See e.g. Williamson (2008) for a presentation of the long-term trend of terms of trade between rich and poor countries.

7 See Fig. 1: Map of the Pitted Ware Culture.
} 


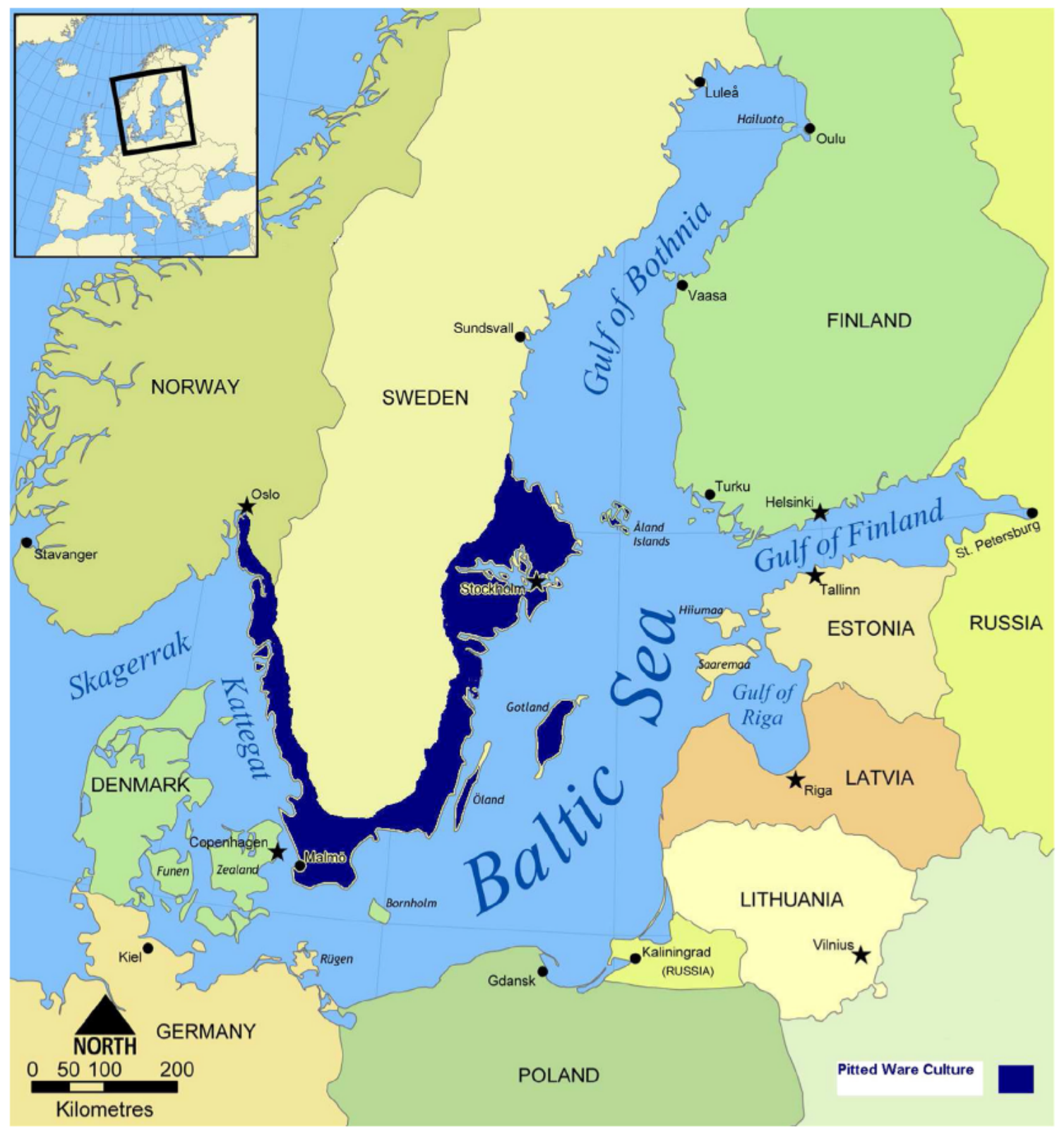

Fig. 1. Map of the Pitted Ware Culture.

the Early Neolithic. By the Middle Neolithic, despite there is a growing reliance on farming of cereals in the TRB areas, but in east ern Sweden evidence for farming rapidly declines. Such change cannot be explained by environmental conditions since the climate was warmer than before.

On Middle Neolithic TRB sites in western and southern Sweden, over $90 \%$ of the faunal material belong to domesticated animals, and the majority of these are from cattle. Subsequently to the TRB, the economy of the BAC has been described as based on small scale horticulture and sheep pastoralism, complemented with inland hunting. In contrast to the subsistence of both farming cultures, TRB and BAC, missing from the PWC settlements are bones from cattle and sheep/goat. In fact the PWC sites contain bones only from wild animals. Therefore, the Pitted Ware people were "pure" HG, i.e. they based their reliance only from food pro curement, especially marine resources (Eriksson, 2004). The PWC coastal sites display fish, birds, seals, and also whales in northern Norway. Indeed, during the Late Mesolithic and Early Neolithic phases the climate changed and the Baltic again became a saline sea. The return to saline conditions is likely to have had a positive effect on the productivity of the marine environment and this seems to have led to marine resources becoming the dominant source of subsistence.

\section{Origin and fate of the PWC: new insights from recent studies}

The origin of the PWC has always been controversial and two main approaches have been developed until recently. The first one favours an explanation endogenous to the TRB culture: the PWC is considered as the result of a reversion to the hunting gathering sub sistence strategy among TRB peoples (Fornander, 2011; Iversen, 2013). The second approach considers that the PWC has a different origin from TRB, being related either to the late Mesolithic hunter gatherer complexes of northern Europe, or to populations ancestral to modern Saami people of present day northern Scandinavia. 
The notion of two separate Middle Neolithic groups of people in this region rather than different endeavours by only one group is now supported thanks to archaeological records related to the material culture (pottery) as well as to DNA studies. Concerning pot tery, it has been noted an eastern influence on PWC, in the extensive use of pits and later comb decoration on the pottery, but also in the making of zoo and anthropomorphic clay figurines, which is attested in both Finland and the Baltic states (Larsson, 2009).

Recent archaeogenetic studies of animals and humans remains associated with the TRB and the PWC suggest that these two mate rial cultures represent two different genetic populations (Eriksson, 2004; Fornander et al., 2008; Malmström et al., 2009, 2010, 2015; Skoglund et al., 2012, 2014). Thus, the PWC did not come from a reversion of some TRB peoples. Moreover, despite their presence in Scandinavia at the early stages of neolithisation, the Pitted Ware people are not the direct ancestors of modern Scandinavians but are more closely related to contemporary populations of the east ern Baltic region (Malmström et al., 2009).

\subsection{The fate of the PWC}

Another important question is the fate of the Pitted Ware people for which some new insights have been recently provided by two different genetic studies. The first one is about lactase persistence. By investigating an allele associated with lactase persistence, it appeared that the allele frequency was very low (5\%) in the Pitted Ware population, and was dramatically different from the extant Swedish population (74\%) (Malmström et al., 2010). It is thus possi ble to conclude that this difference in frequency could not have arisen by genetic drift and is either due to selection or, more likely, to replacement of HG populations by sedentary agriculturalists.

The second study (Skoglund et al., 2014) based on analyses of mtDNA and genomic sequences showed that Scandinavian Neo lithic farmers exhibited an important degree of hunter gatherer related admixture. In contrast, Scandinavian HG displayed no sig nificant evidence of introgression from farmers. Neolithic farming communities seem to have absorbed HG while advancing north through Europe while HG groups show no signs of absorbing Neo lithic people. These findings also suggest that the Pitted Ware peo ple were, as were the others Stone Age foraging groups, historically in low numbers (Shennan and Edinborough, 2007).

\section{Evidence of contacts and trade between foragers and farmers}

Several studies have shown that, in northern Europe, wider landscapes were involved in the Neolithic economic system. More specifically, TRB was most likely not a local but a regional econ omy, where not only prestige items and humans were circulating but also basic components of subsistence. For instance, using strontium, oxygen and carbon isotope analysis of teeth from domestic animals, Sjögren and Price (2013) have notably demon strated the high mobility of domestic animals, particularly of cattle but also of sheep. In addition to these trade relationships between farmers communities, contacts and trade also existed between for agers and farmers. According to various models of contact between foragers and farmers, such as the well known "availability model" (Zvelebil and Rowley Conwy, 1984), the neolithisation of the PWC can be one of the possible outcomes of these contacts. Indeed, the engagement of the PWC in trade relationships with its neighbour ing farmer communities (TRB to BAC) is supported by several evi dences provided from archaeological records.

\subsection{Settlement location and connectivity}

Most of the PWC settlements were located on the shores of the sea or of major lakes. The conventional view would stress that the people maintaining these sites focused on seal hunting and fishing, and this would be the most important factor in explaining their locations. However, many PWC sites also contain exotic material and/or objects that indicate contacts over large geographical areas. Thus, the site location characteristics and the material culture probably have an explanation that goes beyond pure economy and hunting strategies for which the seashore and wetland areas can be understood as only ecological niches on the margins. It is more likely that the PWC sites also constituted a network of sea routes and important places for creating social interaction, such as the ones required for trade since coastal sites served as meeting places for people from widely dispersed areas (von Hackwitz, 2010). Such view is reinforced if the seashore is considered as a continuation of the traditional use of particular ecological niches as in eastern Middle Sweden. As such, the seashore developed a kind of sense of place, which allowed for maritime connectivity. Likewise on the Baltic Sea islands, the archaeological material does not exhibit remoteness, rather connectivity, integration and con tact with the mainland. The sites were made in relation to the unrestricted space of the seashore. With their location on the coast of mainland Scandinavia and the Baltic Sea islands, hence with the main activities taking place on the beaches, the PWC sites undoubtedly characterise a maritime economic system. Further more, they also display connections to TRB complex societies fur ther south. The sea opens up the potential for navigation, colonisation, and trade. The sea should be understood as allowing movement and connections rather than a barrier for dividing social space (Jennbert, 2014).

\subsection{Long distance exchange of "Exotic"}

At least from the fifth millennium, long distance exchanges existed between northern and central Europe, i.e. between foragers and farmers communities (Chapman, 2008; Czekaj Zastawny et al., 2011; Klassen, 2012). Similarly, there is evidence of exchange of stones tools between the PWC and the farming communities. In addition to huge amounts of fragmented pottery, many PWC sites also contain exotic material and/or objects that indicate contacts over large geographical areas. Some authors may argue that there really is a sharp divide in the Early Neolithic archaeological mate rial across central Scandinavia, with the TRB in the south and the PWC in the north. There are, however, also traces of contacts across this border in the form of imported exotic objects (Hallgren, 2012). It should be noted that these exchanges were oriented in both directions, from PWC to farmers, and from the latter to the former. For instance, various types of "exotic" TRB axes ${ }^{8}$ have been found north of the northernmost known TRB sites in Scandinavia. Symmet rically and besides finds typical of the TRB have been also found a few exotic artefacts in the form of slate tools (e.g. a knife of banded red and green slate) originating from the hunter gatherer society of northern Scandinavia. The presence of both TRB axes from the south and slate tools from the north shows that the groups of people who lived in Scandinavia participated in wide ranging social networks that directly or indirectly stretched from Denmark to northern Norway/northern Sweden, and right across the border between hun ter gatherers and farmers.

\subsection{Intensive seal hunting and pottery}

On most PWC sites, if not all, there are evidences of intensive exploitation of seals, as confirmed by the presence of numerous bones of seals remains. For instance, data from Västerbjers (Got

\footnotetext{
${ }^{8}$ Including polygonal battle-axes, point-butted and thin-butted axes made from flint or greenstone.
} 
land) clearly show that the people were almost completely depen dent on seals for food (Eriksson, 2004). At Ajvide (Gotland), an extensive dark cultural layer was saturated with seal train oil which could have resulted from purely economic activity (Rowley Conwy, 2004). The PWC is even sometimes called "the seal culture". Moreover, the PWC sites have provided a very large number of pottery shreds. It is thus possible to surmise that both evidence were linked, i.e. the Pitted Ware people were hunting many sea mammals (especially seals) not only for their own sub sistence, but mainly to get seal oil and fat in order to trade these produces with farmers by means of potteries (used as containers). In fact, even if these communities of hunter gatherers were quasi sedentary, they were involved in long distance trade using the northern European marine coastal routes and extensive river net work, reinforced by seal hunting and production of seal oil as a locally produced trading commodity. Specialised exploitation of seal and other coastal resources increased in northern Europe from the late Mesolithic and among ceramic using hunter gatherers. This is evident from faunal data, site locations and human dietary analyses. Moreover, one may suggest that the adoption of ceramics facilitated in a major way the processing and storage of seal oil and so encouraged specialisation and trade (Zvelebil, 2008).

\section{Specialisation and trade between PWC foragers and TRB to BAC farmers}

In northern circum Baltic Europe, characteristically variable spatial and seasonal distribution of natural resources elicited a dual technological and economic response, comprising strategies of diversification and specialisation. Economic diversification con sisted of encounter foraging of a wide range of resources. Economic specialisation consisted of interception of seasonally aggregated migratory resources, especially sea mammals, seal in particular, but also anadromous fish, waterfowl, fur bearing animals, and reindeer in the North. It should be noted that trade which can be seen as a form of social storage is one of the four strategies (with mobility, diversification, and storage) of risk reducing mech anisms available to foragers in order to manage seasonal and inter annual variation of food resources. It is thus possible, based on the evidence previously presented (Section 4), to deduce that the Pit ted Ware people have decided once they have had contact with farmers, to maintain their hunter gatherer lifestyle, to get spe cialised in the hunt of sea mammals, and to engage in trade with farmers. Therefore, northern Europe was, during the millennium when the PWC was present, characterised by a dual economy, with two different and economically specialised communities foragers and farmers linked through trade.

Foragers and farmers communities trade with each other when, on their own, they do not have the resources, or capacity to satisfy their own needs and wants. By developing and exploiting their domestic scarce resources, communities can produce a surplus, and trade this for the resources they need. Goods and services are likely to be traded for several reasons. Purchased goods may be cheaper, or of better quality. They may also be more easily avail able or simply more appealing than locally produced goods. In many instances, no local alternatives exist, and buying is essential. As first analysed by Smith (1776), the production of goods and ser vices in communities that need to trade is based on two fundamen tal principles, the division of labour and specialisation. When applied to different communities, a division of labour means that communities produce just a small range of goods or services. Spe cialisation is the second fundamental principle associated with trade, and results from the division of labour. Given that each com munity is given a specialist role, it is likely to become an efficient contributor to the overall production. Hence, specialisation can generate further benefits in terms of efficiency and productivity. Specialisation is increased when communities use their scarce resources to produce just a small range of products in high volume. This allows a surplus of good to be produced, which can then be sold to the other community. This means that goods and resources must be bought from the other community that have also spe cialised, and produced surpluses of their own.

As demonstrated by Ricardo (1817) for international trade, the total output i.e. the output of both communities in our case would increase when the principle of comparative advantage ${ }^{9}$ is applied by communities to determine what goods and services they should specialise in producing. In other words, if communities apply the principle of comparative advantage, combined output will be increased in comparison with the output that would be produced if the two communities remained in autarky. Both communities have therefore mutual advantages to develop trade of goods resulting from specialisation according to comparative advantages. The fol lowing question in our special case is what were the comparative advantages of foragers and of farmers? Without loss of generality, we may consider that each community has two groups of economic activities, one related to food resources and the other one being about non food resources. Concerning food resources, it is obvious that the labour productivity of agro pastoralists is higher than the labour productivity of foragers. Thus, farmers have an absolute advantage in the production of food resources. For the non food resources, the comparison is less obvious, mainly because most goods produced by both communities are different goods or low sub stitutes. Anyway, since farmers have an absolute and hence implic itly a comparative advantage in the production of food resources, they should specialised in this activity. In a symmetric way, foragers become specialist in the production of non food resources. ${ }^{10}$ Based on such specialisation, trade between the two communities was pos sible and beneficial to both parties, at least in the short term.

\section{Labour productivity in foraging and farming economies}

We have previously assumed that both communities had eco nomic activities related to food resources and to non food resources. However, a difference exists between the two economic systems. Indeed, farmers have an economy based on production: food resources are produced (by means of plants cultivation and animals domestication) and non food resources are also produced (e.g. pottery, stone axes, weaving). On the contrary, foragers have an extractive economy, i.e. a resource based economy dependent on harvesting or extracting natural resources. Indeed, food resources are not produced, but obtained from the wild through hunting, gathering, collecting and fishing. Non food resources (furs, amber, seal fat, forest products) are not produced as well, but extracted from the nature and can be considered as raw mate rials. We therefore have two different economic systems, a produc tive economy and an extractive economy. However, both economies are based on the same input, namely labour. Compar ison of both economic systems is then possible through the com parison of the marginal productivity of labour in each one.

For foragers, labour productivity is decreasing in both sectors, i.e. for food and non food resources. This comes from the fact that the resources extract by foragers are non renewable or at best are exhaustive. More precisely these resources are "produced" by the nature. At any time, a given stock of these resources is available

\footnotetext{
${ }^{9}$ Comparative advantage relates to how much productive or cost efficient one producer is than another.

${ }^{10}$ It should be noted that this does not mean that foragers give up food procurement, at least during a while. Becoming a specialist of an economic activity simply means that more scarce resources - mainly labour - are devoted to this activity.
} 
and each extraction by foragers leads to a reduced level of the remaining stock. More labour will be needed in the future to extract the same amount of resources, i.e. the marginal productiv ity of labour is decreasing.

\subsection{Labour productivity and the expansion of farming}

Concerning labour productivity in agriculture, we may consider two different and subsequent stages. First, during the beginning of farming let us assumed during the Early Neolithic and the Middle Neolithic A it is likely that agriculture exhibited constant returns to labour, a fair assumption given the abundance of suitable land at that time. In a second time e.g. starting from the Middle Neolithic B farming had spread everywhere in Northern Europe and thus arable soils were not available. It seems obvious that agricultural communities would choose to settle first in areas of high produc tivity. Less desirable areas (due to economic, climatic, ecologic, geographic or social barriers) are bypassed in favour of more opti mal locations. As these favourable areas become colonised, subse quent colonisation events will take place in the immediate vicinity of the initial colony; in the latter however the returns to each farmer decline (Svizzero, 2015). Indeed, any additional increase of the agricultural output necessitated the cultivation of soils char acterised by lower fertility and hence the productivity of labour became decreasing, this is the so called "law of diminishing returns".

\section{The long-term decline in terms of trade}

In order to explain how the neolithisation process has occurred in northern Europe, i.e. why the PWC has finally disappeared, we must therefore explain why the economic specialisation described previously of both communities has been more inten sive with the passage of time. For that purpose, we examine the causes and the consequences of the trend of the terms of trade. When the latter were declining for foragers, they led to the "im miserising growth" of the PWC and then, in the long term, to the neolithisation of the latter.

A community's terms of trade measures a community's sales prices in relation to its purchases prices. We claim that farmers' terms of trade improved while they worsened for foragers and this evolution led to the final stage of the neolithisation process. When a community's terms of trade improve, it means that for every unit of goods sold it can buy more units of goods. So potentially, a rise in the terms of trade creates a benefit in terms of how many goods need to be sold to buy a given amount of purchased goods. A wors ening term of trade indicates that a community has to sell more to purchase a given quantity of products. For foragers, the unfavour able evolution of terms of trade can be explained from both sides of a market analysis.

\subsection{The relative evolution of labour productivities}

Let us first consider the supply side. Since labour is the only scarce input in both economic systems, its productivity determines the production cost and then the price of output. Thus, the relative evolution of labour productivities determines the evolution of terms of trade. As shown previously for the farming economic sys tem, two stages have existed.

During the first stage, early farmers had a constant marginal productivity of labour while the latter was decreasing for foragers. In other words, foragers incurred an increasing cost for any addi tional unit of output they extracted and consequently the price of the raw materials they traded was increasing while the price of agricultural product remained constant. The terms of trade were hence in favour of foragers during this first stage, i.e. they became wealthier through trade with their neighbouring farmers.

During the second stage, the productivity of labour used for agriculture started to decrease; thus both economic systems, forag ing and farming, were characterised by a decreasing productivity of labour. The evolution of terms of trade i.e. of the relative prices of traded products was determined by the relative evolution of labour productivities in both economic systems. It is widely agreed that the Neolithic way of life was associated with a huge popula tion increase, the so called "Neolithic Demographic Transition" (Bocquet Appel and Bar Yosef, 2008). In order to feed a growing population, new lands (with decreasing fertility) should have been cultivated and it is thereby a fair assumption to consider that the labour productivity of farming has continuously decreased once the Neolithic Demographic Transition has started. When the labour productivity decreased faster for farming than for foraging, the terms of trade led to the impoverishment of foragers.

\subsection{The Singer Prebisch Thesis}

Let us now consider the demand side of the market. For that purpose, we may adapt to our particular situation i.e. trade between foragers and farmers the Singer Prebisch Thesis. ${ }^{11}$ This thesis is well known in the literature on economic development of countries; it forms the basis of economic dependency theory. The thesis states that, over time, the terms of trade for commodities and primary products deteriorate relative to manufactured goods. This hypothesis contributed to the general view that it was danger ous to rely on raw materials to secure growth and development. A common explanation for the phenomenon is the observation that the income elasticity of demand for manufactured goods is greater than that for primary products. Therefore, as incomes rise, the demand for manufactured goods increases more rapidly than demand for primary products. In our particular case, we may simi larly assume that the income elasticity of demand for resources pro duced by farmers is greater than that of raw materials extracted by foragers. This means that just to keep their standard of living and maintain the existing development gap, foragers relying on extract ing raw materials, whose terms of trade decline, must continually increase output.

\section{The long-term impoverishment of foragers-traders and the complete neolithisation of Northern Europe}

On both sides of the market we have economic mechanisms explaining endogenously that foragers' terms of trade are worsen ing with the passage of time, i.e.:

when the labour productivity decreased faster for farming than for foraging,

and/or when the income elasticity of the demand for resources produced by farmers is greater than that of raw materials extracted by foragers.

\subsection{Foragers' dilemma: collapse or impoverishment}

In such circumstance, i.e. when the terms of trade lead to the impoverishment of foragers, the latter have three possible strategies.

Firstly, they may choose reversion. In that case, they stop trad ing with farmers and return to their original way of life. If, from a social point of view, such outcome namely independence is possible, it is less likely from an economic point of view. Indeed,

\footnotetext{
11 See Prebisch (1950) and Singer (1950).
} 
foragers should decide to work in economic activities where the productivity of their labour is higher and we know that the labour productivity associated with food procurement is very low, com pared for instance to labour productivity in agriculture. ${ }^{12}$ An addi tional reason explaining why do hunter gatherers ultimately abandon foraging rather than disengaging from the unfavourable trade is that they want to keep up in with the market of manufac tured goods. It is however possible that some cases of reversion have occurred but they probably existed during short periods of time.

Secondly, they may decide to gather more raw materials and to intensify their trade with farmers. However, if such strategy is cho sen, it may lead to the collapse of the foraging economy. Indeed, if extraction is too important, it may reach the carrying capacity of a given resource and then resulted in its extinction. For instance the extinction of the Pleistocene megafauna has been explained as a consequence of overkill (Smith, 1975; Bulte et al., 2006). In the for aging economic system, overexploitation of resources may often be the outcome since there is no private property, and thus the "tra gedy of commons" can easily happen (North and Thomas, 1977). From an economic point of view, extinction means that the pro ductivity of labour suddenly drops to zero; when it occurs, foragers are therefore unable to trade and probably even to survive.

Thirdly, some foragers may decide to give up foraging and to become farmers. However, such strategy does not lead for the remaining foragers to a better issue. Indeed, the ex foragers/ new farmers induce the cultivation of new lands with lower fertil ity which in turn leads to a faster decrease of the labour productiv ity in agriculture, and thus to a deeper deterioration of terms of trade. Such cumulative causation process may explain why all HG finally abandon their lifestyle in the long term.

To sum up, whatever strategy the foragers adopt, their situation is worse off; either they collapse or they get impoverished and they finally give up their lifestyle.

\subsection{The neolithisation process}

Foragers and farmers were initially expecting mutual gains from trade based on the division of labour and specialisation according to their respective comparative advantage. However, it appears that after a while and due to an unfavourable evolution of terms of trade, trade is not in favour of foragers. In order to feed a growing population, farmers must cultivate new land associated with lower fertility. This means that labour productivity is decreas ing faster in agriculture than in the foraging economy, that the prices of agricultural products are increasing faster than the prices of raw materials sold by foragers, leading to a further deterioration of terms of trade. The unchanged structure of supply intensifies the structural dependency and, regardless of growth, it leads for for agers to immiserising growth (Bhagwati, 1958).

In the long term, the impoverishment of the Pitted Ware people induced by their trade with TRB to BAC farmers led them to "cooperate" further with the latter communities, and therefore to progressively give up what defined their own culture. This is illus trated, for instance, by the existence of a hybrid form of pottery displaying traits from the ceramic traditions of both the BAC and the PWC, at the end of the Middle Neolithic B (2700 2200 BC). It is argued that the blending of styles and techniques are not the inevitable result of coexistence in the same region, but rather a vital clue to the strategies used by individuals and groups when communicating with each other through material culture (Larsson, 2003). This rapprochement between foragers and farmers is also supported by recent archaeogenetic studies (Skoglund et al.,

\footnotetext{
12 Please note that, as we have assumed, even if the labour productivity decreases faster in agriculture than in foraging, the level of the labour productivity can be higher in agriculture compared to foraging.
}

2014) showing that Neolithic farming communities seem to have absorbed hunter gatherers while advancing north through Europe while hunter gatherer groups show no signs of absorbing Neolithic people.

\section{Conclusion}

In northern Europe, the Pitted Ware people were finding their subsistence mainly through the Baltic Sea they depended upon it and on the seasonal behaviour of seals and fish. Thus, they were part of a wide network around the Baltic Sea. During approxi mately one millennium (from 3300 to $2300 \mathrm{BC}$ ), these people were engaged in exchange and trade with the farming communities, TRB to BAC. Despite numerous contacts which are well documented by archaeological records transition to farming has occurred only at the end of a long term process. Therefore, the neolithisation can not be considered as the outcome of a short term process such as the one implied by social competition between hunter gatherers. It cannot also be considered as the result of a deliberate choice done by hunter gatherers who finally recognised the superiority of agriculture because they could have done it more quickly.

We provide an explanation of the neolithisation process in northern Europe which avoids such shortcomings. Indeed, for us the neolithisation is the involuntary issue of a long term process based upon trade between foragers and farmers. Both communities organised trade between them and get specialised according to their comparative advantages. However, foragers' economy is extractive, i.e. is associated with a decreasing productivity of labour but, due to the scarcity of arable soils which occurred after the beginning of farming, the productivity of labour is also decreas ing for farmers, and it decreases more rapidly compared to for agers' one. Moreover, the demand of the goods extracted and sold by foragers mainly seal oil has low income elasticity. Given both features of their economy, foragers have faced worsening terms of trade in the long term. Trade was not therefore in their favour, implying a process of immiserising growth. In the long term this led the Pitted Ware people or at least most of them to finally give up their way of life, i.e. to adopt agriculture.

\section{References}

Berbesque, J.C., Marlowe, F.W., Shaw, P., Thompson, P., 2014. Hunter-gatherers have less famine than agriculturalists. Biol. Lett. 10, 20130853. http://dx.doi.org/ 10.1098/rsbl.2013.0853.

Bhagwati, J., 1958. Immiserizing growth: a geometrical note. Rev. Econ. Stud. 25 201-205.

Bocquet-Appel, J.P., Bar-Yosef, O. (Eds.), 2008. The Neolithic Demographic Transition and its Consequences. Springer, Netherlands.

Bowles, S., 2011. Cultivation of cereals by the first farmers was not more productive than foraging. PNAS 108 (12), 4760-4765.

Bulte, E., Horan, R.D., Shogren, J.F., 2006. Megafauna extinction: a paleoeconomic theory of human overkill in the Pleistocene. J. Econ. Behav. Organ. 59 (3), 291 323.

Chapman, J., 2008. Approaches to trade and exchange in earlier prehistory: Late Mesolithic - Early Bronze Age. In: Jones, A. (Ed.), Prehistoric Europe: Theory and Practice. Wiley-Blackwell, Oxford, pp. 333-355.

Childe, V.G., 1936. Man Makes Himself. Watts, London.

Cramp, L.J.E., Jones, J., Sheridan, A., Smyth, J., Whelton, H., Mulville, J., Sharples, N., Evershed, R.P., 2014. Immediate replacement of fishing with dairying by the earliest farmers of the northeast Atlantic archipelagos. Proc. Roy. Soc. B 281, 20132372. http://dx.doi.org/10.1098/rspb.2013.2372.

Czekaj-Zastawny, A., Kabacinski, J., Terberger, Th., 2011. Long distance exchange in the Central European Neolithic: Hungary to the Baltic. Antiquity 85 (327), 4358.

Dolukhanov, P., Shukurov, A., Gronenborn, D., Sokoloff, D., Timofeev, V., Zaitseva, G., 2005. The chronology of Neolithic dispersal in Central and Eastern Europe. J. Archaeol. Sci. 32, 1441-1458.

Eriksson, G., 2004. Part-time farmers or hard-core sealers? Västerbjers studied by means of stable isotope analysis. J. Anthropol. Archaeol. 23, 135-162.

Feinman, G.M., Garraty, C.P., 2010. Preindustrial markets and marketing: archaeological perspectives. Annu. Rev. Anthropol. 39, 167-191.

Fischer, A., 2002. Food for feasting? An evaluation of explanations of the neolithisation of Denmark and southern Sweden' in the neolithisation of 
Denmark - 150 years of debate. In: Fischer, A., Kristensen, K. (Eds.), Sheffield Archaeological Monographs, vol. 12. J.R. Collis Publications, Sheffield, pp. 343393.

Fornander, E., Eriksson, G., Lidén, K., 2008. Wild at heart: approaching Pitted Ware identity, economy and cosmology through stable isotopes in skeletal material from the Neolithic site Korsnäs in Eastern Central Sweden. J. Anthropol. Archaeol. 27, 281-297. http://dx.doi.org/10.1016/j.jaa.2008.03.004.

Fornander, E., 2011. Consuming and Communicating Identities. Dietary Diversity and Interaction in Middle Neolithic Sweden. Theses and Papers in Scientific Archaeology, vol. 12. Stockholm University, Stockholm.

Hallgren, F., 2012. A permeable border - long-distance contacts between hunters and farmers in the Early Neolithic of Scandinavia. In: Networks, Interaction and Emerging Identities in Fennoscandia and Beyond. Papers from the Conference held in Tromsø, Norway, October 13-16, 2009. Mémoires de la Société FinnoOugrienne, vol. 265, pp. 139-154.

Iversen, R., 2013. Beyond the Neolithic transition - the 'De-neolithisation' of south Scandinavia. In: Larsson, M., Debert, J. (Eds.), NW Europe in Transition. The Early Neolithic in Britain and South Sweden. British Archaeological Reports 2475. Archaeopress, Oxford, UK, pp. 21-29.

Jennbert, K., 2014. The seashore - beyond monumentality. The case of Pitted Ware coastal sites in southern Sweden. In: Furholt, M., Hinz, M., Mischka, D., Noble G., Olausson, D. (Eds.), Landscapes, Histories and Societies in the Northern European Neolithic. Dr. Rudolf Habelt GmbH, Bonn, Germany, pp. 235-246.

Klassen, L., 2012. Axes of Alpine jade from southern Scandinavia and northernmost Germany. Dan. J. Archaeol. 1 (1), 86-89.

Larsson, A., 2003. Uniting strategies. Material culture in eastern Central Sweden at the end of the Middle Neolithic. In: Samuelsson, C., Ytterberg, N. (Eds.) Uniting Sea. Stone Age Societies in the Baltic Sea Region, vol. 33. OPIA, pp. 132146.

Larsson, A., 2009. Pots, pits and people. Hunter-gatherer pottery traditions in Neolithic Sweden. In: Gheorghiu, D. (Ed.), Early Farmers, Late Foragers, and Ceramic Traditions: On the Beginning of Pottery in the Near East and Europe. Cambridge Scholars Publishing, Cambridge, pp. 239-270.

Larsson, M., 2004. Living in cultural diversity. The Pitted Ware Culture and its relatives. J. Nord. Archaeol. Sci. 14, 61-69.

Malmström, H., Gilbert, M.T., Thomas, M.G., Brandström, M., Storå, J., Molnar, P. Andersen, P.K., Bendixen, C., Holmlund, G., Götherström, A., Willerslev, E., 2009. Ancient DNA reveals lack of continuity between Neolithic hunter-gatherers and contemporary Scandinavians. Curr. Biol. 19, 1758-1762. http://dx.doi.org/ 10.1016/j.cub.2009.09.017.

Malmström, H., Linderholm, A., Liden, K., Storå, J., Molnar, P., Holmlund, G., Jakobsson, M., Götherström, A., 2010. High frequency of lactose intolerance in a prehistoric hunter-gatherer population in northern Europe. BMC Evol. Biol. 10 89. http://dx.doi.org/10.1186/1471-2148-10-89.

Malmström, H. et al., 2015. Ancient mitochondrial DNA from the northern fringe of the Neolithic farming expansion in Europe sheds light on the dispersion process. Philos. Trans. Roy. Soc. B 370, 20130373. http://dx.doi.org/10.1098/ rstb.2013.0373.

North, D.C., Thomas, R.P., 1977. The first economic revolution. Econ. Hist. Rev. 30, 229-241 (Second Series).

Polanyi, K., 1944. The Great Transformation: The Political and Economic Origins of Our Time. Farrar \& Rinehart, New York.

Prebisch, R., 1950. The Economic Development of Latin America and its Principal Problems. UN Document No. E/CN.12/89/Rev. 1. United Nations, Lake Success, New York.

Pryor, F.L., 2007. Immiserizing growth as seen by Bhagwati, Samuelson, and Others. J. Econ. Educ. 38 (2), 208-214.

Ricardo, D., 1817. On the Principles of Political Economy and Taxation. John Murray, London, http://www.econlib.org/library/Ricardo/ricP.html.
Rowley-Conwy, P., 2004. Ajvide. In: Bogucki, P., Crabtree, P.J. (Eds.), Ancient Europe; 8000 B.C. -1000 A.D. Encyclopaedia of the Barbarian World. Charles Scribners \& Sons, New York, pp. 435-438.

Rowley-Conwy, P., 2011. Westward Ho! The spread of agriculturalism from central Europe to the Atlantic. Curr. Anthropol. 52 (S4), S431-S451. http://dx.doi.org/ 10.1086/658368, The Origins of Agriculture: New Data, New Ideas.

Shennan, S., Edinborough, K., 2007. Prehistoric population history: from the Late Glacial to the Late Neolithic in Central and Northern Europe. J. Archaeol. Sci. 34, 1339-1345.

Singer, H.W., 1950 (1975). The distribution of gains between investing and borrowing countries. In: The Strategy of International Development: Essays in the Economics of Backwardness. Macmillan, London.

Sjögren, K.-G., Price, T.D., 2013. A complex Neolithic economy: isotope evidence for the circulation of cattle and sheep in the TRB of western Sweden. J. Archaeol. Sci. 40, 690-704. http://dx.doi.org/10.1016/j.jas.2012.08.001.

Skoglund, P., Malmström, H., Raghavan, M., Storå, J., Hall, P., Willerslev, E., Gilbert, M.T.P., Götherström, A., Jakobsson, M., 2012. Origins and genetic legacy of Neolithic farmers and hunter-gatherers in Europe. Science 336, 466-469. http:// dx.doi.org/10.1126/science.1216304.

Skoglund, P., Malmström, H., Omrak, A., Raghavan, M., Valdiosera, C., Günther, T. Hall, P., Tambets, K., Parik, J., Sjögren, K.-G., 2014. Genomic diversity and admixture differs for Stone-Age Scandinavian foragers and farmers. Science 344, 747-750. http://dx.doi.org/10.1126/science.1253448.

Smith, A., 1776 (2008). An Inquiry into the Nature and Causes of the Wealth of Nations: A Selected Edition. In: Kathryn Sutherland (Ed.), Oxford Paperbacks, Oxford, UK.

Smith, V.L., 1975. The primitive hunter culture, Pleistocene extinction, and the rise of agriculture. J. Polit. Econ. 83, 727-755.

Smith, M.E., 2004. The archaeology of ancient state economies. Annu. Rev. Anthropol. 33, 73-102.

Sørensen, L., Karg, S., 2012. The expansion of agrarian societies towards the North new evidence for agriculture during the Mesolithic/Neolithic transition in Southern Scandinavia. J. Archaeol. Sci. XXX, 1-17.

Svizzero, S., 2015. The long-term decline in terms of trade and the neolithization of Northern Europe. Scand. Econ. Hist. Rev. http://dx.doi.org/10.1080/03585522. 2015.1008566.

Svizzero, S., 2015. Farmers' spatial behaviour, demographic density dependence and the spread of neolithic agriculture in Central Europe. Doc. Praehistor. 42.

Svizzero, S., Tisdell, C., 2014. Theories about the commencement of agriculture in prehistoric societies: a critical evaluation. Rivista Storia Econ. 3, 255-280. http://dx.doi.org/10.1410/78237.

Svizzero, S., Tisdell, C., 2015. The persistence of hunting and gathering economies. Soc. Evol. Hist. 14 (2), 3-25.

Von Hackwitz, K., 2010. What makes a place? Feature perspectives on site locations. In: Larsson, Å.M., Papmehl-Dufay, L. (Eds.), Uniting Sea II. Stone Age Societies in the Baltic Sea Region. Uppsala University, OPIA 51, pp. 195-210.

Williamson, J.G., 2008. Globalization and the great divergence: terms of trade booms, volatility and the poor periphery, 1782-1913. Eur. Rev. Econ. Hist. 12 (3), 355-391.

Zvelebil, M., Rowley-Conwy, P., 1984. Transition to farming in northern Europe: a hunter-gatherer perspective. Norw. Archaeol. Rev. 17, 104-127.

Zvelebil, M., 2001. The agricultural transition and the origins of Neolithic society in Europe. Doc. Praehistor. XXVIII, 1-26.

Zvelebil, M., 2004. Pitted Ware and related cultures of Neolithic Northern Europe. In: Bogucki, P., Crabtree, P.J. (Eds.), Ancient Europe; 8000 B.C. - 1000 A.D. Encyclopaedia of the Barbarian World. Charles Scribners \& Sons, New York, pp. 431-435.

Zvelebil, M., 2008. Innovating hunter-gatherers: the Mesolithic in the Baltic. In: Bailey, G. (Ed.), Mesolithic Europe. Cambridge University Press, Cambridge, pp. $18-59$. 